\title{
Study on the Relationship between the Oceanic Nino Index and Surface Air Temperature and Precipitation Rate over the Kingdom of Saudi Arabia
}

\author{
Yehia Hafez \\ Department of Meteorology, King Abdulaziz University, Jeddah, Saudi Arabia \\ Email: ysalam@kau.edu.sa
}

Received 21 April 2016; accepted 17 May 2016; published 20 May 2016

Copyright (C) 2016 by author and Scientific Research Publishing Inc.

This work is licensed under the Creative Commons Attribution International License (CC BY). http://creativecommons.org/licenses/by/4.0/

\section{(c) (;) Open Access}

\begin{abstract}
Abnormal weather conditions and extreme weather existed over the Kingdom Saudi Arabia (KSA) through the last decades. The present paper investigates the relationship between the Oceanic Nino Index (ONI) and variability of surface air temperature and precipitation rate over KSA through the period from 1950 to 2015 year. The NCEP/NCAR Reanalysis of monthly data sets of the mean surface air temperature and precipitation rate for the domain of the KSA is used. In addition, El Nino3.4 monthly data through the period (1950-2015) are used. For that period, the data set of the three months moving average of Nino3.4 anomaly, Oceanic Nino index (ONI), is used and analyzed. The time series, anomaly and correlation coefficient techniques are used to analyze the data sets through the present study. The results revealed that the KSA climate parameters, temperature and precipitation rates are controlled by $\mathrm{ONI}$ mainly in the autumn and winter seasons.
\end{abstract}

\section{Keywords}

ONI, El Nino3.4, Surface Air Temperature, Precipitation Rate, KSA

\section{Introduction}

In the last decades, the King Saudi Arabia (KSA) suffered from extreme weather events. Extreme heat waves and flash floods became more frequent. There are several scientific literatures challenging the climate changes and the extreme temperature and precipitation over KSA [1]-[6] and more recently by [7] [8]. It is found that the extreme weather over the KSA is related to the atmospheric circulation. The climate of the KSA is instructed by 
the El Nino Southern Oscillation (ENSO) and other atmospheric circulations such as centers of high and low-pressure [7]. For wet season from November to April, the 6-month averaged Arabian Peninsula rainfall is negatively correlated with ENSO for the period from 1950 to 1979. Meanwhile, positive is correlated to ENSO for the period from 1981 to 2010. The multidecadal variations attributed to the variations in Indian Ocean Sea Surface Temperature (SST) anomalies are accompanied by ENSO [9]. However, the ENSO phenomenon affects the weather and climate of distinct regions of the globe. ENSO is a recurring climate pattern involving changes in the temperature of waters in the central and eastern tropical Pacific Ocean. The ENSO phenomenon is the combination of SOI and El Nino. It is controlling the global atmospheric surface temperature and precipitation [10]-[21] and more recently by Curtis and Douglass [22]. El Nino events are a prominent feature of weather and climate variability with global climatic impacts. It is found that increasing frequency of extreme El Nino events is due to greenhouse warming [23]. The Oceanic Nino Index (ONI) is one measure of the coupled oceanatmosphere phenomenon ENSO. The ONI is the National Oceanic and Atmospheric Administration (NOAA) primary indicator for monitoring El Nino and La Nina, which are opposite phases of the climate pattern called the "ENSO" for short. NOAA considers El Nino conditions to be present when the ONI is +0.5 or higher, indicating the east-central tropical Pacific is significantly warmer than usual. La Nina conditions exist when the ONI is -0.5 or lower, indicating the region is cooler than usual. The ONI tracks the running 3-month Sea Surface Temperature (SST) anomaly in the east-central tropical Pacific between $120^{\circ}-170^{\circ} \mathrm{W}$ (Nino 3.4 region). Departures based on a set of improved homogeneous historical SST analyses (Extended Reconstructed SST ERSST.v4) [24]. Events are defined as 3 consecutive overlapping 3-month periods at or above the $+0.5^{\circ}$ anomaly for warm (El Nino) events and at or below the -0.5 anomaly for cold (La Nina) events. The threshold is further broken down into Weak (with a 0.5 to 0.9 SST anomaly), Moderate (1.0 to 1.4), Strong (1.5 to 1.9) and Very Strong $(\geq 2.0)$ events Lui et al., (2015). However, the impacts of El Nino in weather and climate change conditions challenged and it found that these impacts covered wide regions over the globe [25]-[28]. The present work aims to investigate the relationship between the ONI and the surface air temperature and precipitation rate over KSA through the period (1950-2015).

\section{Data and Methodology}

\subsection{Data}

The NCEP/NCAR Reanalysis project is using a state-of-the-art analysis/forecast system to perform data assimilation, within resolution of $2.5^{\circ} \times 2.5^{\circ}$ degree lat/long grid, using past data from 1948 to 2016. Monthly data sets of the surface air temperature and precipitation rate over the King Saudi Arabia (KSA) for the period from the year 1950 to the year of 2015 is used. This data provided by the NOAA/OAR/ESRL PSD, Boulder, Colorado, USA and [29]. In addition, the monthly data of El Nino $3.4\left(5^{\circ} \mathrm{S}-5^{\circ} \mathrm{N}\right.$ and $\left.170^{\circ} \mathrm{W}-120^{\circ} \mathrm{W}\right)$ over Pacific Ocean from 1950 to 2015 year are used. However, NCEP data sets of temperature and precipitation domain considered in the present work extended to $12^{\circ} \mathrm{N}-32^{\circ} \mathrm{N}, 33^{\circ} \mathrm{E}-60^{\circ} \mathrm{E}$ for KSA, see Figure 1. Moreover, data of the three-months moving average anomaly of El Nino 3.4, Oceanic Nino Index (ONI), for 65 years period from the year 1950 to the year of 2015 is used. This three-month running mean of Sea Surface Temperature (SST) anomalies of Nino 3.4 is according to ERSST.v4, 1971-2000 base period [24]. These data sets obtained from website through the internet of the Climate Prediction Centre at http://www.cpc.ncep.noaa.gov/products/monitoring data/.

\subsection{Methodology}

Anomaly methodology has been used to analysis the surface air temperature and precipitation rate over the KSA through the study period (1950-2015). The climatic mean values of the surface air temperature and the precipitation rate are taken through the period (1981-2010). Whereas, the period of climatic mean must be a 30 year mean. In addition, the climatic mean through the period (1981-2010) is the recently climatic mean for climatological studies.

\subsubsection{Calculation of Seasonal and Annual Averages}

The calculations of seasonal and annual averages of temperature and precipitation for each grid point in the domain of KSA, [9 × 12-degree lat/long grids] done. Seasonally and annual averages for the temperature, precipitation 


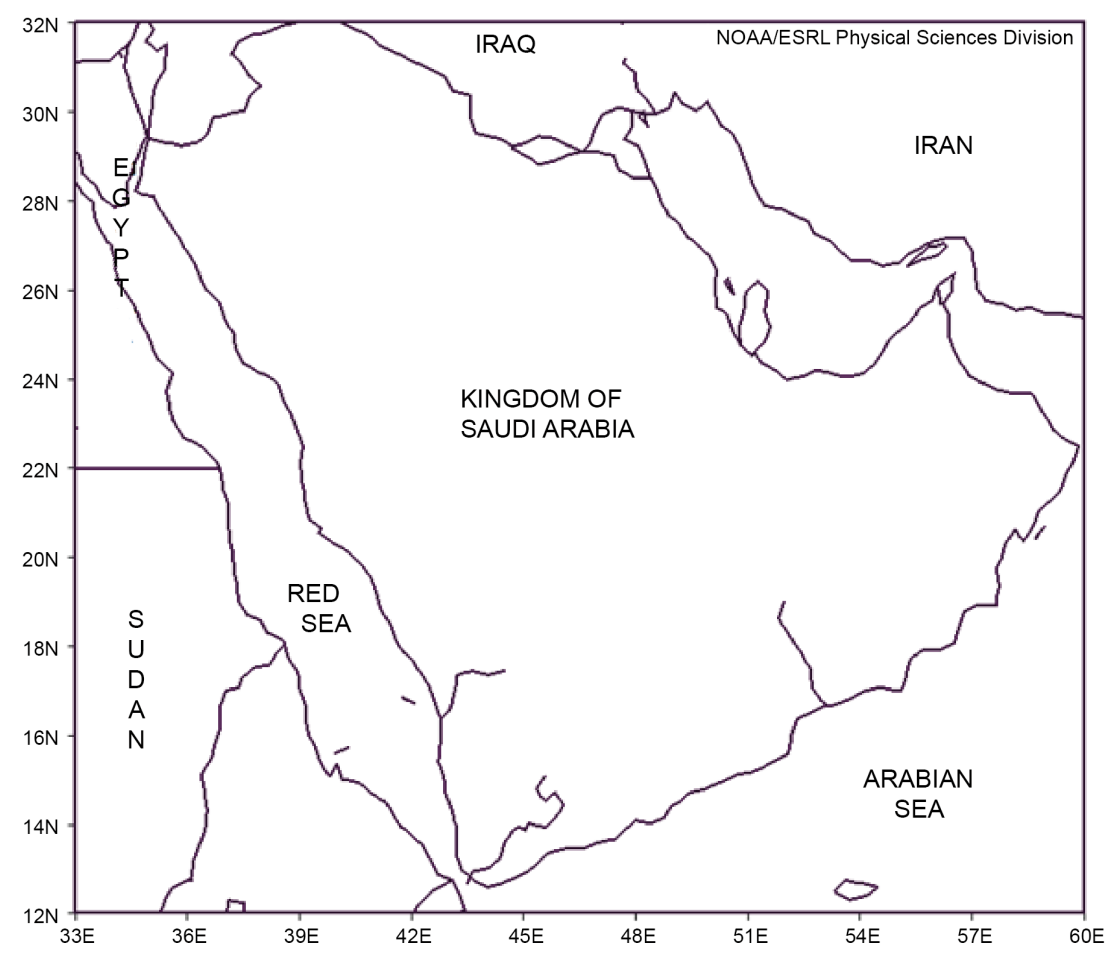

Figure 1 . The study area of Kingdom of Saudi Arabia region $\left[12^{\circ} \mathrm{N}-32^{\circ} \mathrm{N}, 33^{\circ} \mathrm{E}-60^{\circ} \mathrm{E}\right]$.

and El Nino 3.4 have been calculated using the NCEP/NCAR reanalysis monthly data sets along the period 1950-2015. The seasonal averages through the year are calculated; e.g., for the winter season averages of air temperature, precipitation over the KSA have been calculated using the NCEP/NCAR reanalysis monthly data sets for winter season (December + January + February)/3. The climatic mean of the temperature and precipitation rate are taken for the period (1981-2010). The spring, summer, autumn and annual means of surface air temperature, precipitation rate, El Nino 3.4 calculated in the same manner. However, the interactive plotting and analysis NCEP/NCAR software program is used for this analysis.

\subsubsection{Linear Correlation Method}

For a linear correlation analysis of the ONI datasets and the mean surface air temperature and precipitation rate over the KSA during the study period 1950-2015, the methodology of Monte-Carlo has been used, [30]. Based on this methodology, a correlation of 0.2 would be significant for degrees of freedom 66. In addition, the time series analysis and the linear correlation method according to Pearson correlation method, [31] is used. The trends for all indices calculated using a simple least-squares linear regression. Statistical significance was determined using the Kendall-tau test. A trend deemed to "statistically significant" if it has at least $90 \%$ significance.

\subsubsection{Local Significance and Calculation of Correlation Patterns}

For given monthly and seasonally resolved means of surface air temperature and precipitation rate at each grid point correlated with El Nino3.4. Each grid point correlation is t-tested for local significance using [32] allowing for temporal autocorrelation according to [30] method. To estimate the correlation, we use the Monte-Carlo methodology. The field significance statistic is the area-weighted average absolute correlation of a given correlation map. The field-significance threshold is the 95th percentile of a 1000-member Monte-Carlo population.

\section{Results and Discussion}

\subsection{The Variability of Monthly Surface Air Temperature and Precipitation Rate over KSA during the Period (1950-2015)}

The NCEP/NCAR reanalysis monthly data of the surface air temperature and precipitation rate $(\mathrm{mm} /$ day) for 
KSA through the period from the year of 1950 to the year of 2015 used. These data sets are analyzed by time series analysis and anomaly method and it became clear that:

1. The annual surface air temperature composite mean value reached to its maximum value $\left(+30^{\circ} \mathrm{C}\right)$ over the southeastern part of KSA. The annual surface temperature composite reached to its minimum value $\left(21^{\circ} \mathrm{C}\right)$ over the northwestern part of KSA during the period of study (1950-2015), see Figure 2(a).

2. Analysis of the anomaly of surface air temperature composite shows that the southwestern part of KSA has a negative temperature anomaly of $\left(-0.75^{\circ} \mathrm{C}\right)$ less than its normal. Meanwhile, the northern part of KSA has a positive temperature anomaly reached to $\left(+0.75^{\circ} \mathrm{C}\right)$ more than its normal value over the northwestern part of KSA through the study period, see Figure 2(b).

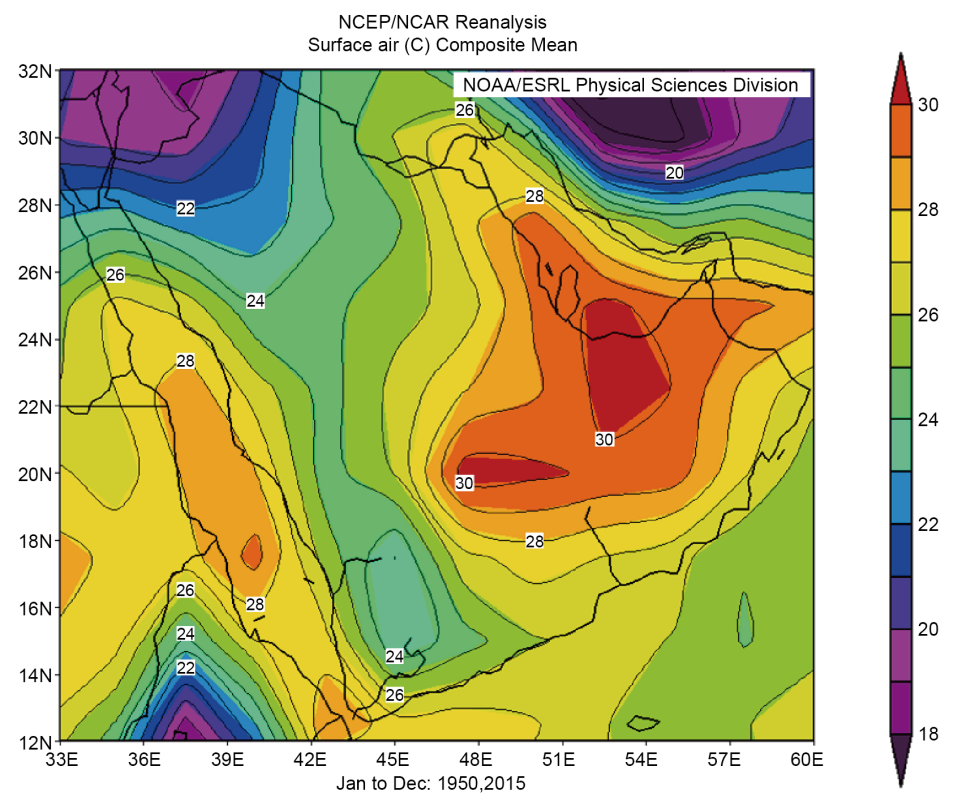

(a)

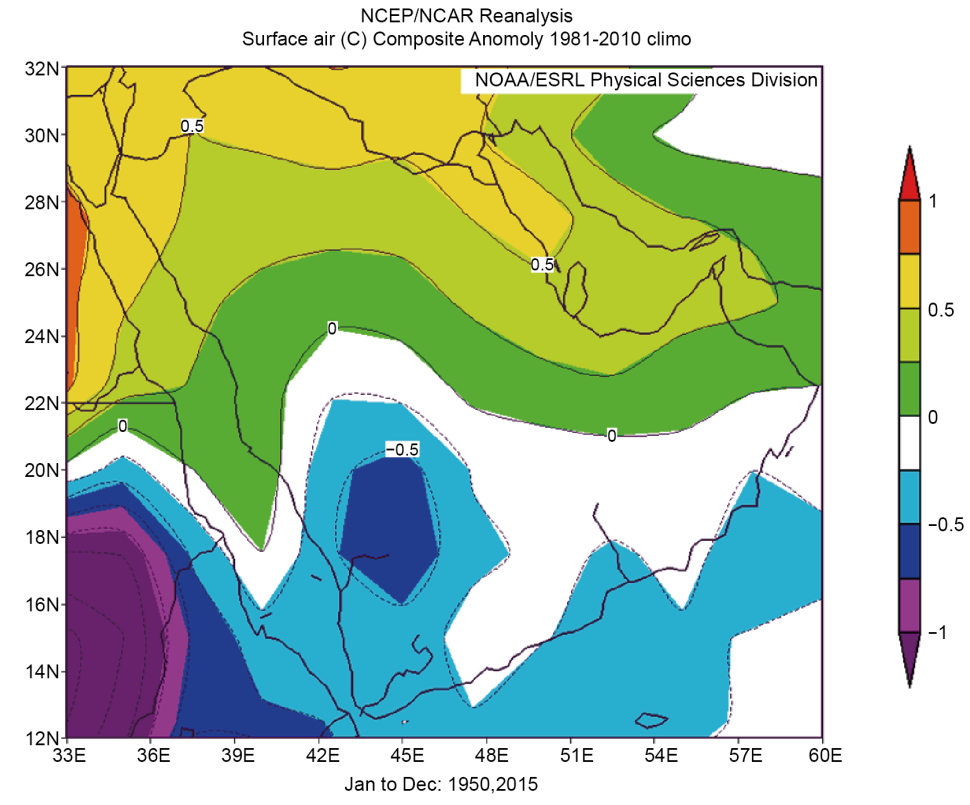

(b)

Figure 2. The distribution of composite [(a) annual surface air temperature; (b) annual anomaly of mean of surface air temperature] over the KSA during the period (1950-2015). 
3. Time series analysis of the annual mean surface air temperature over the KSA clear that there is cooling existed over the KSA through the interval between the year of 1950 and the year of 1980. Through that interval, the mean surface air temperature over the KSA reached to its extreme negative anomaly $\left(-1.3^{\circ} \mathrm{C}\right)$ on the year of 1963. The outstanding warming over the KSA appears after the year of 1997 to the year of 2015. The maximum temperature anomaly over KSA exists on the year of 2010 and it is reached to $\left(+0.98^{\circ} \mathrm{C}\right)$ more than its normal value. However, the climatic mean of surface temperature over the KSA is $\left(+25.21^{\circ} \mathrm{C}\right)$ for the period (1981-2010). The linear trend of annual surface air temperature over the KSA is a positive trend with slope $\left(+0.0159^{\circ} \mathrm{C}\right.$ year $\left.^{-1}\right)$ through the period (1950-2015). It illustrated from Figure 3.

4. Analysis of the annual precipitation rate (mm/day) composite mean for KSA through the period (1950-2015) shows that all of KSA has a precipitation rate less than $(1 \mathrm{~mm} /$ day) except a small part at the southwestern part of KSA it is more than ( $1 \mathrm{~mm} /$ day) and reached to its maximum value ( $2 \mathrm{~mm} /$ day) through the study period. As it illustrated in Figure 4(a).

5. It is clear that the northern western part of KSA has a positive anomaly of precipitation rate reached to $(+0.2$ $\mathrm{mm} /$ day). In addition, there exist of a positive anomaly of precipitation rate of $(+0.6 \mathrm{~mm} /$ day) over only the small part in the southwestern of KSA. Meanwhile, the southeastern part of KSA has a negative anomaly of precipitation rate reached to ( $-0.2 \mathrm{~mm} /$ day), as it shown in Figure 4(b).

6. Analysis of the time series for annual precipitation rate anomaly revealed that there is an outstanding increase in the precipitation rate over KSA through the period of interval (1950-1963). The precipitation rate anomaly reached to its positive extreme value $(+10.8 \mathrm{~mm} /$ day $)$ on the year of 1960 . After the year of 1973 , the annual precipitation rate value oscillates around its normal value until the year of 2008. However, the normal climatic mean of precipitation rate over the KSA is (3.76 mm/day) for the period (1981-2010). After the year, 2008 it is notice that there is continues increase in the precipitation rate rather than its normal value until the year of 2015. It is noticed that the linear trend of annual precipitation rate is a negative trend $\left(-0.084\right.$ (mm/day) year $\left.{ }^{-1}\right)$, through the period (1950-2015), see Figure 5.

\subsection{Analysis of Variability of Oceanic Nino Index (ONI) through the Period (1950-2015)}

The data of Oceanic Niño Index (ONI, three month running mean of ERSST.v4 SST anomalies in the Nino 3.4 region $\left(5^{\circ} \mathrm{N}-5^{\circ} \mathrm{S}, 120^{\circ} \mathrm{W}-170^{\circ} \mathrm{W}\right)$ had been used and analyzed through the period (1950-2015). This data analyzed by time series method. Events are defined as 3 consecutive overlapping 3-month periods at or above the +0.5 anomaly for warm (El Nino) events and at or below the -0.5 anomaly for cold (La Nina) events. The threshold is further broken down into Weak (with a 0.5 to 0.9 SST anomaly), Moderate (1.0 to 1.4), Strong (1.5 to $1.9)$ and Very Strong $(\geq 2.0)$ events. The results are the following:

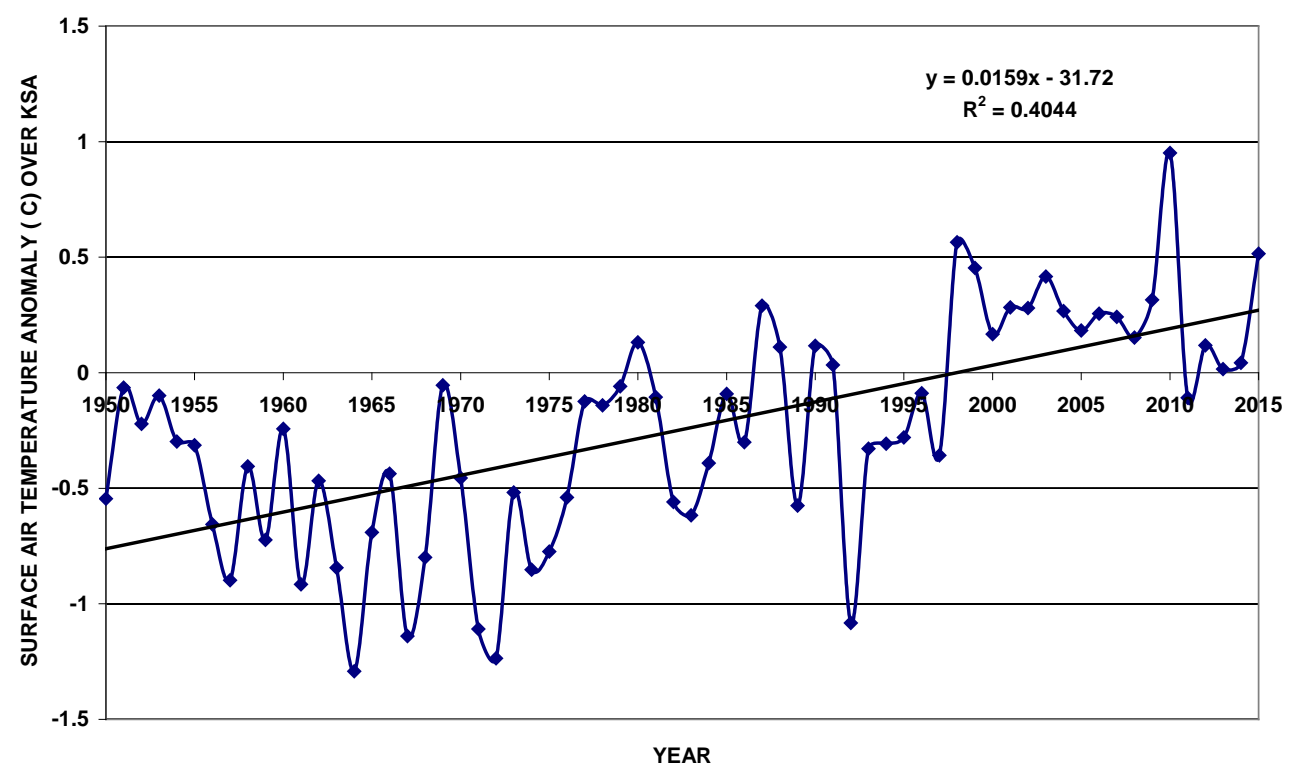

Figure 3. Time series of anomaly of the annual surface air temperature over the KSA through the period (1950-2015). 


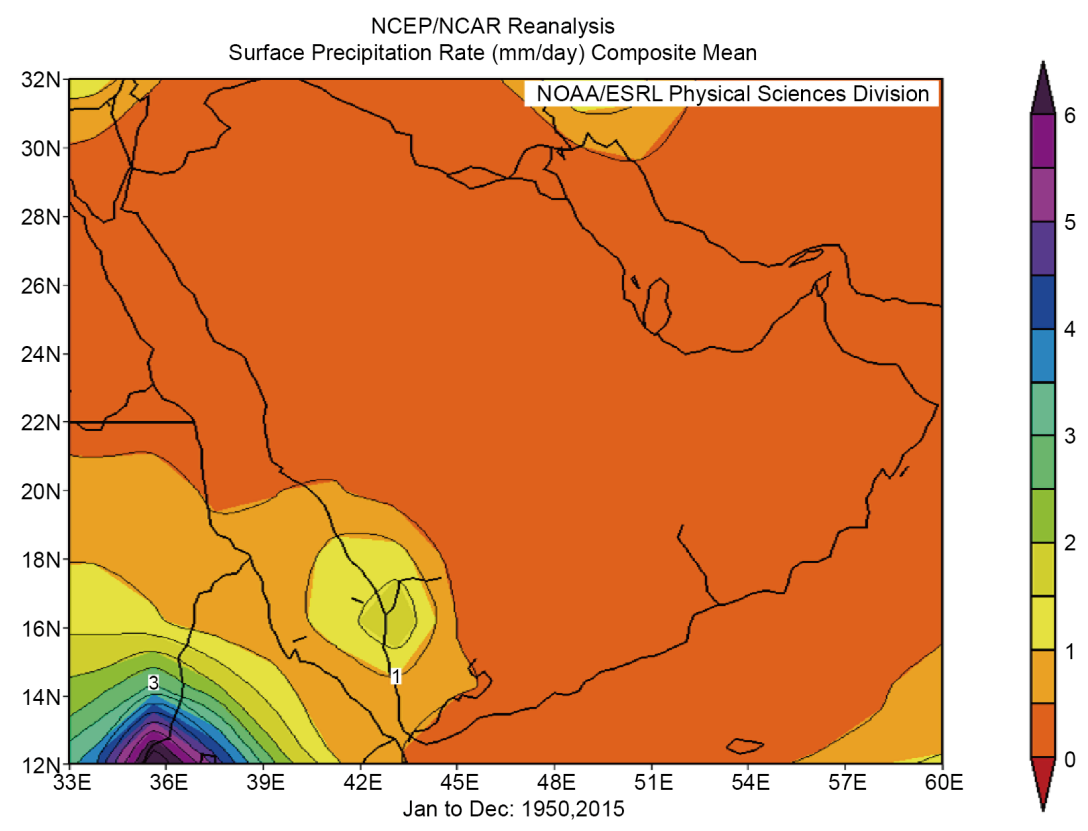

(a)

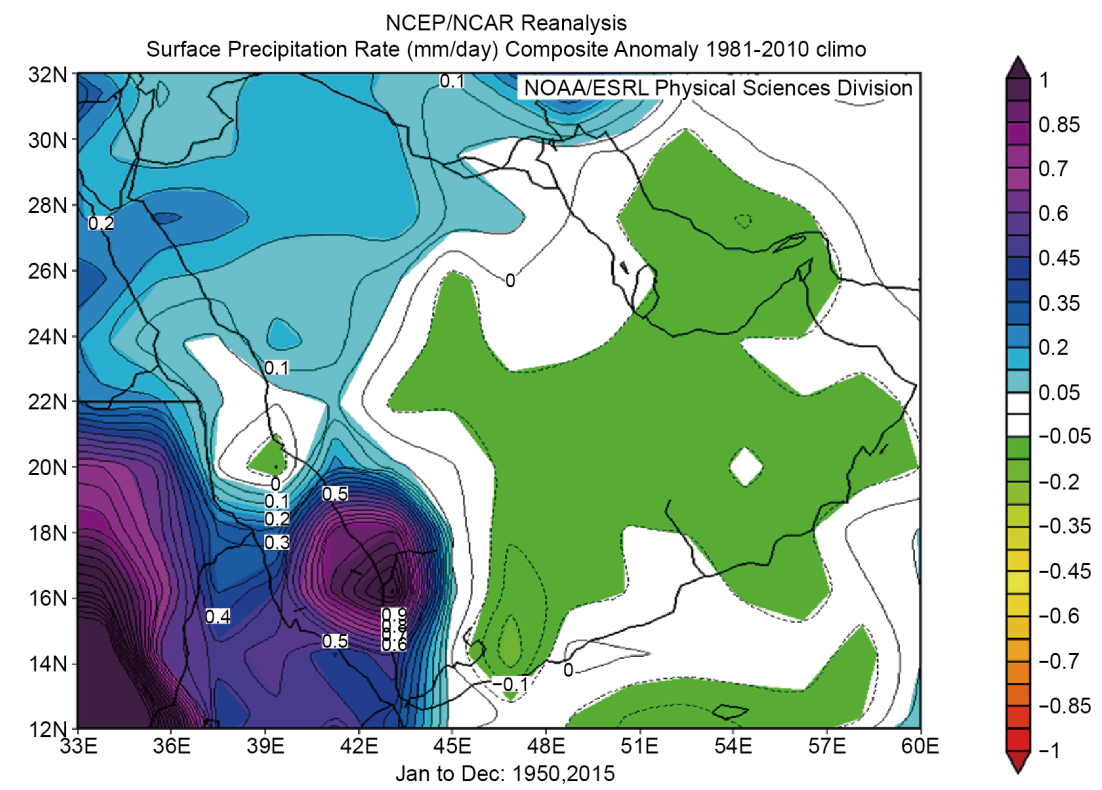

(b)

Figure 4. The distribution of composite [(a) annual precipitation rate (mm/day); (b) annual anomaly of mean annual precipitation rate (mm/day)] over the KSA during the period (1950-2015).

1) Figure 6 shows the variability of monthly El Nino 3.4 anomaly through the period (1950-2015). It is clear that SST anomalies in central Pacific Ocean varies from year to year irregular and ranged from $+2.3^{\circ} \mathrm{C}$ to $-2.2^{\circ} \mathrm{C}$ through the period of study (1950-2015).

2) Figure 7 shows the variability of ONI index, through the period (1950-2015). It is clear that the range of SST anomaly varies in range $+2.2^{\circ} \mathrm{C}$ and $-1.9^{\circ} \mathrm{C}$.

3) It becomes clear that ONI index is enhancement of monthly El Nino3.4 anomaly data. The ONI index is more liable to identify El Nino, La Nina, and ENSO cases, see Figure 7.

4) There exist of 20 cases of El Nino and 17 cases of La Nina with total frequency of 30\% and 26\% respectively through 65 years of period (1950-2015) as it is clear in Table 1. 


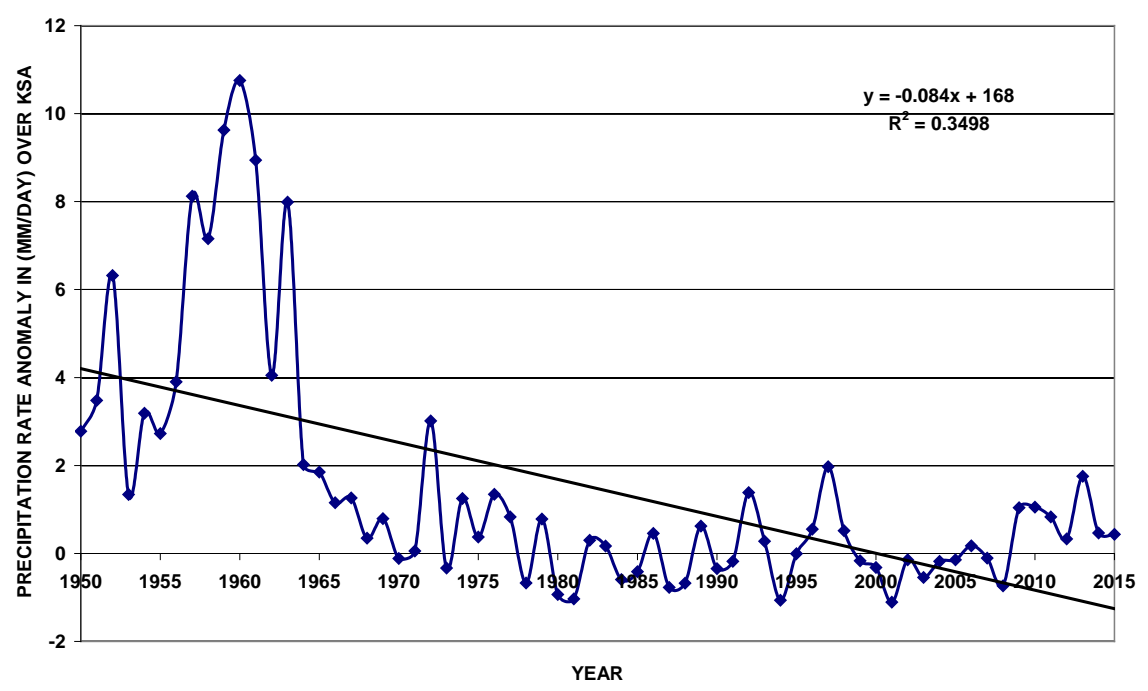

Figure 5. Time series of anomaly of the annual precipitation rate (mm/day) over the KSA through the period (1950-2015).

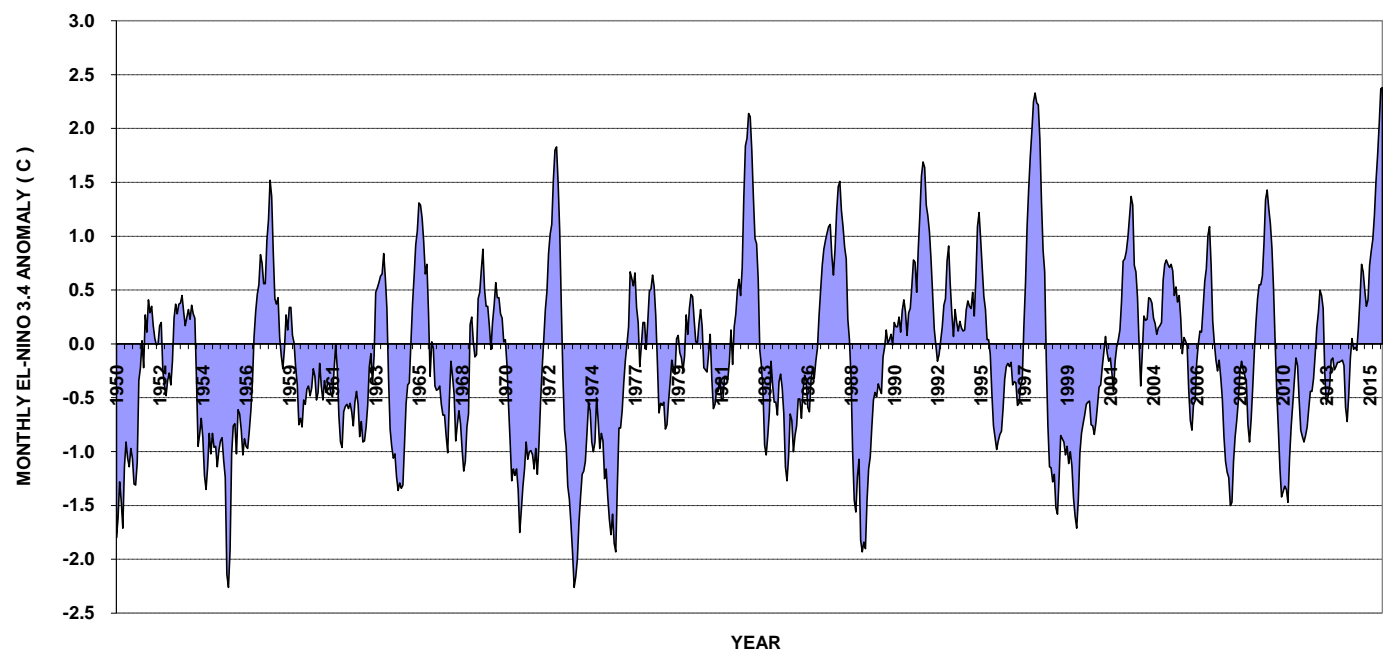

Figure 6. Time series of anomaly of the monthly El Nino 3.4 through the period (1950-2015).

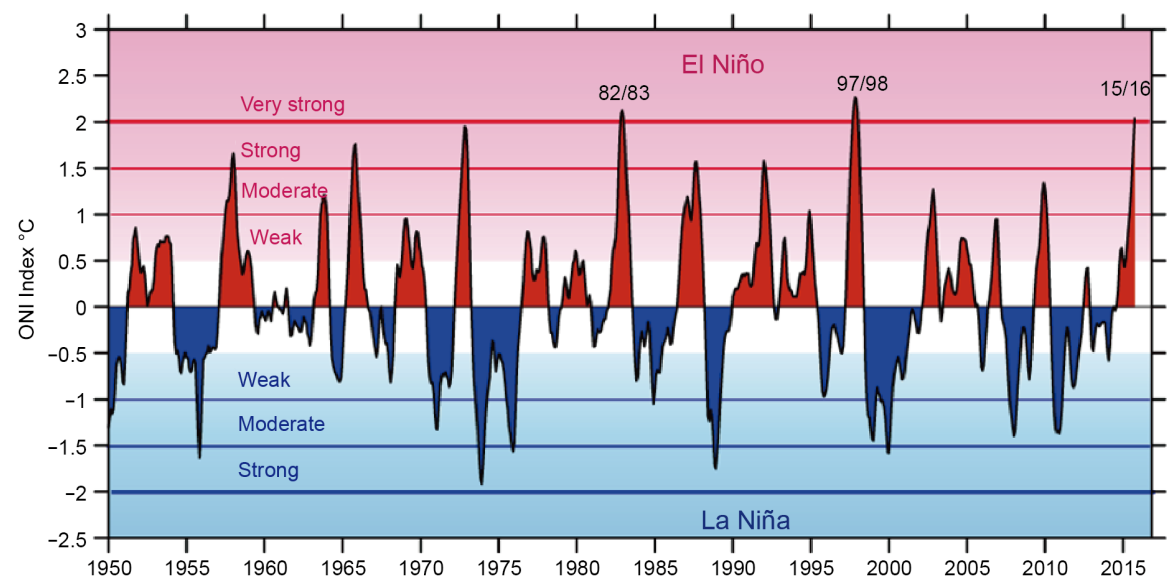

Figure 7. The Oceanic Nino Index (ONI) with El Nino and La Nina strength years through the period of study (1950-2015) [Source: (contributed by K Trenberth),

https://climatedataguide.ucar.edu/climate-data/nino-sst-indices-nino-12-3-34-4-oni-and-tni]. 
Table 1. The characteristics of El Nino and La Nina case through the period (1950-2015).

\begin{tabular}{cccccccc}
\hline Phenomena & \multicolumn{2}{c}{ El Nino } & \multicolumn{3}{c}{ La Nina } \\
\hline Strength & Weak & Moderate & Strong & Very Strong & Weak & Moderate & Strong \\
\hline Number of cases & 8 & 6 & 3 & 3 & 8 & 6 & 3 \\
Frequency & $12 \%$ & $9 \%$ & $4 \%$ & $4 \%$ & $12 \%$ & $9 \%$ & $4 \%$ \\
Total number & \multicolumn{2}{c}{20 Cases } & & 17 Cases \\
Total frequency & \multicolumn{2}{c}{$30 \%$} & & $26 \%$ \\
\hline
\end{tabular}

5) El Nino and La Nina cases has the same number and frequency for weak, moderate and strong cases. Whereas, the number and frequency is $(8,12 \%),(6,9 \%)$ and $(3,4 \%)$ weak, moderate and strong cases respectively as shown in Table 1.

6) There are three cases of very strong El Nino for the years, 1982/1983, 1997/1998 and 2015/2016, see Figure 7.

7) El Nino and La Nina cases together represents of 56\% of the study period of 65 years from 1950 to 2015. About $44 \%$ of the study period, the central Pacific Ocean is in natural case.

\subsection{Study the Relationship between the ONI and Surface air Temperature and Precipitation Rate over the KSA through the Period (1950-2015)}

Here we are using the monthly data of the El Nino3.4, ONI, and the surface air temperature and precipitation rate over the KSA to find out the relationship between ONI and weather conditions for KSA during the period (1950-2015). The moving averages through the year has taken for the months as the following abbreviation manner. DJF: December, January, and February months. JFM: January, February and March months. FMA: February, March, and April months. MAM: March, April and May months. AMJ: April, May and June months. MJJ: May, June and July months. JJA: June, July and August months. JAS: July, August and September months. ASO: August, September and October months. SON: September, October and November months. OND: October, November and December months, NDJ: November, December and January months. The Monte-Carlo correlation coefficient technique and Pearson correlation method used to reach this goal. Analysis of these data sets observed that:

1) The distribution of annual surface air temperature over the KSA correlated to El Nino3.4 mainly over the southwestern part of KSA. The significant positive correlation is +0.32 over the southwestern part of KSA through the period of study (1950-2015), see Figure 8(a).

2) The distribution of annual precipitation rate over the KSA correlated to El Nino3.4 mainly over Jeddah, central and southeastern of KSA. The significant positive correlation coefficient +0.24 over these parts of KSA. Meanwhile, there is a negative correlation over the northwestern part of KSA through the period of study, see Figure $8(\mathrm{~b})$.

3) For winter season (Dec.-Feb.) there is a positive significant correlation (+0.3) between El Nino3.4 and surface air temperature over the southern part of KSA. Meanwhile, over Jeddah, the correlation is a negative correlation less than -0.2 . Moreover, it is clear that there is a positive correlation +0.2 between the precipitation rate and El Nino3.4 over southern part of KSA see Figure 9 and Table 2.

4) For spring season (Mar.-May) there is no significant correlation between El Nino3.4 and surface air temperature over the southern part of KSA. Meanwhile, there is a positive correlation +0.3 between the precipitation rate and El Nino3.4 over southeastern part of KSA and a negative correlation - 0.4 over southwestern part of KSA, see Figure 10 and Table 2.

5) For summer season (Jun.-Aug.) there is a positive significant correlation (+0.3) between El Nino3.4 and surface air temperature over the southwestern part of KSA. Meanwhile, it is clear that there is a negative correlation -0.3 between the precipitation rate and El Nino3.4 over western part of KSA see Figure 11 and Table 2.

6) For autumn season (Sep.-Nov.) there is a positive significant correlation reached to (+0.5) between El Nino3.4 and surface air temperature over the southwestern part of KSA. In addition to that, there is a positive correlation reached to +0.5 between the precipitation rate and El Nino3.4 over central part of KSA see Figure 12 and Table 2. 


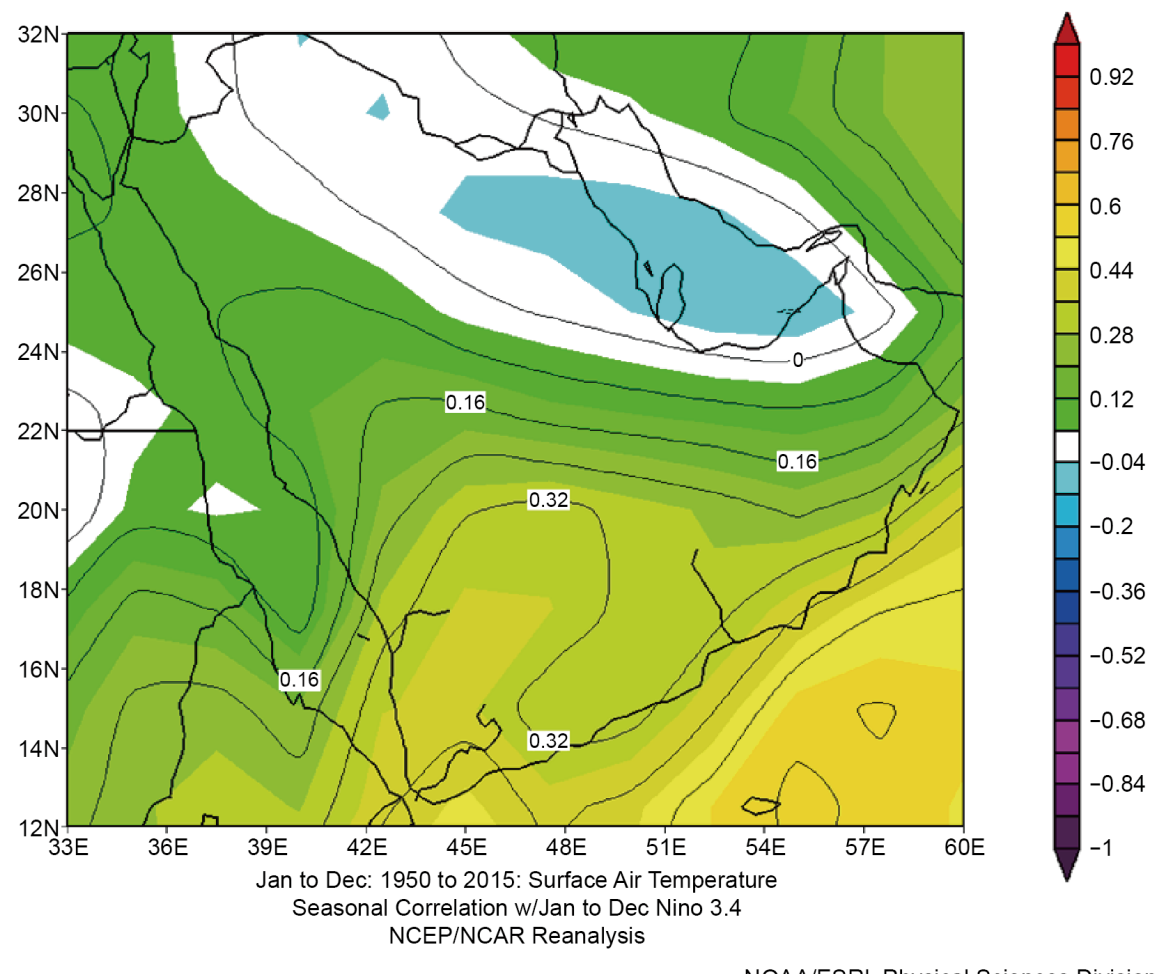

(a)

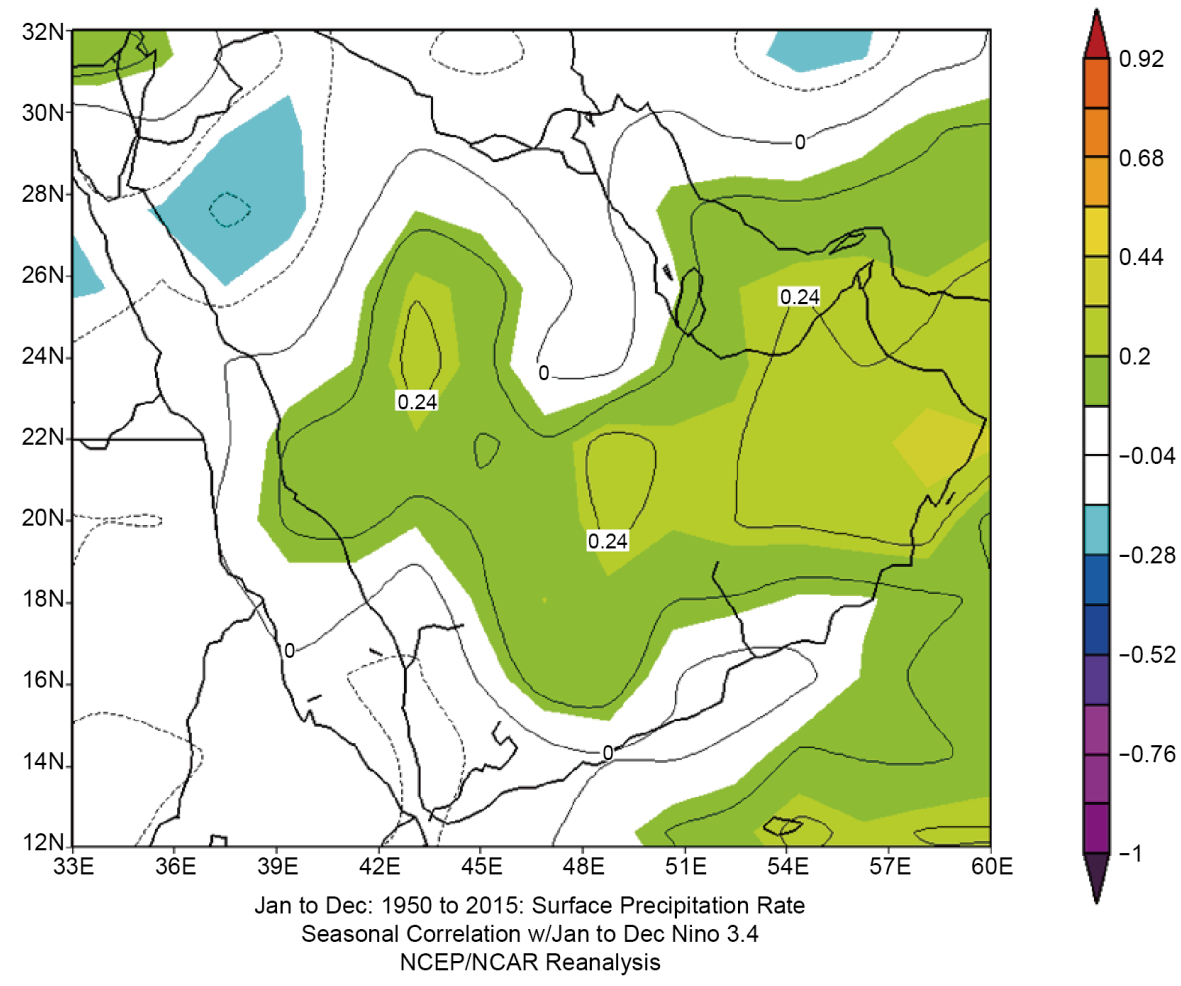

NOAA/ESRL Physical Sciences Division

(b)

Figure 8. The distribution of annual correlation coefficient between El Nino3.4 and [(a) the surface air temperature; (b) precipitation rate] over the KSA through the period of 1950 to 2015. 


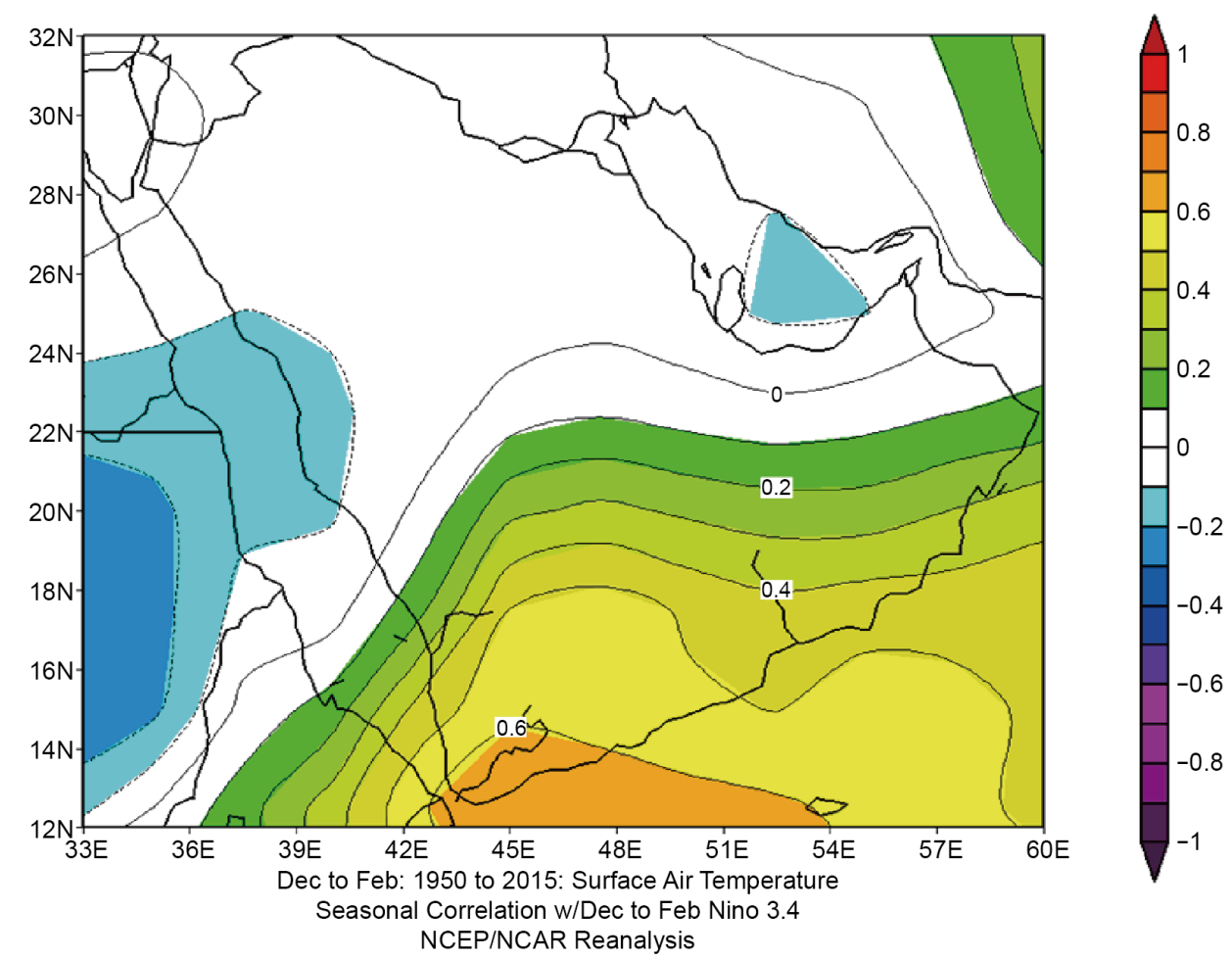

NOAA/ESRL Physical Sciences Division

(a)

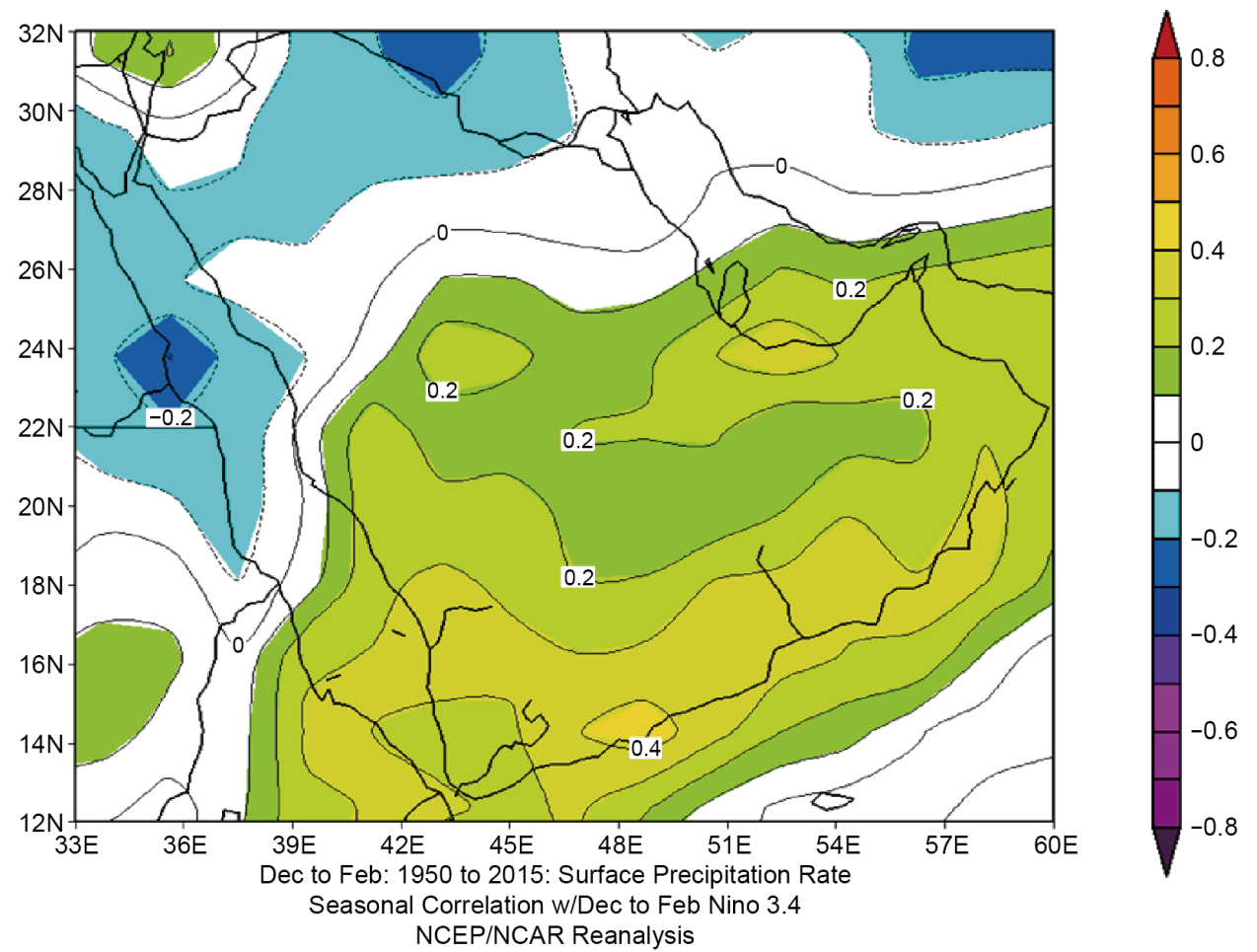

NOAA/ESRL Physical Sciences Division

(b)

Figure 9. The distribution of winter correlation coefficient between El Nino3.4 and [(a) the surface air temperature; (b) precipitation rate] over the KSA through the period of 1950 to 2015. 


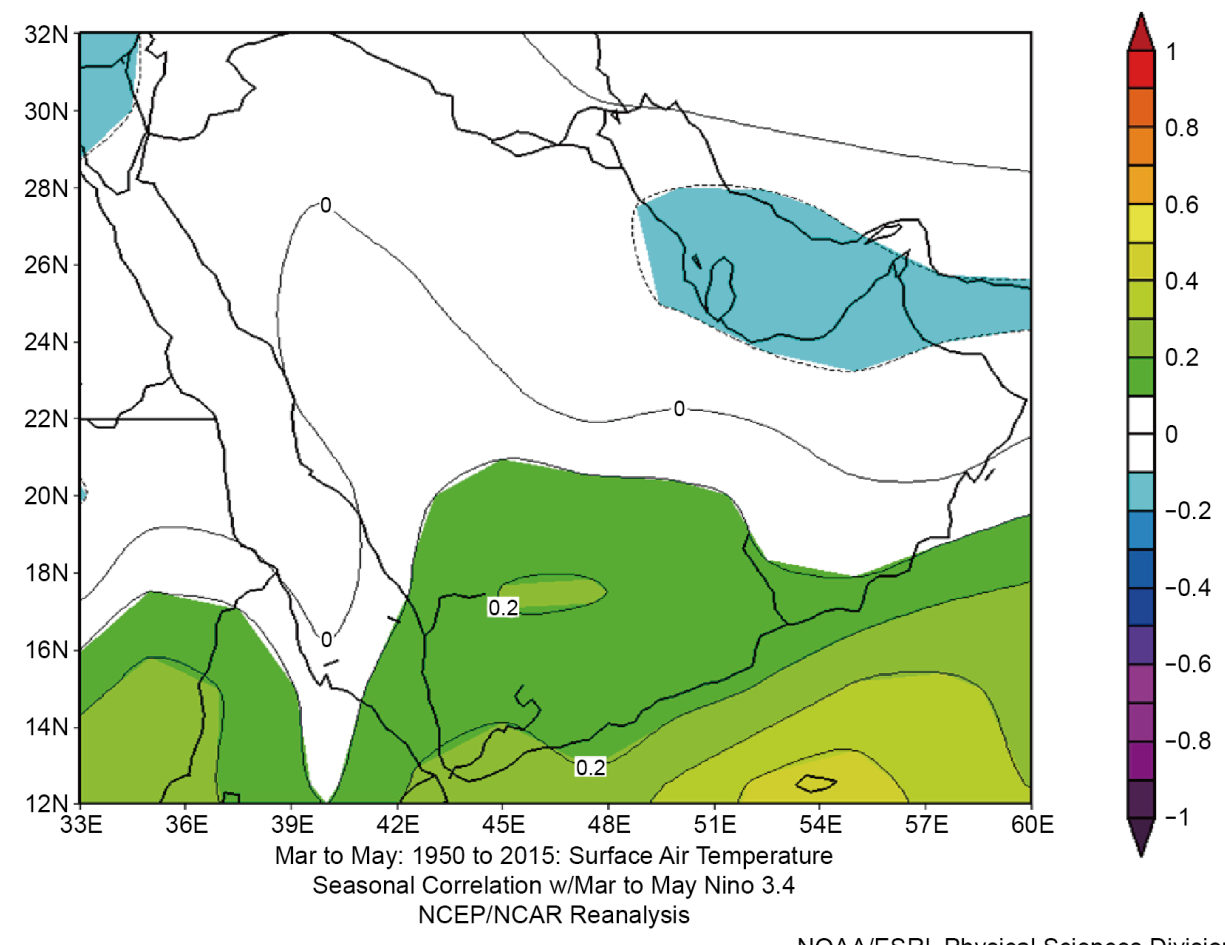

(a)

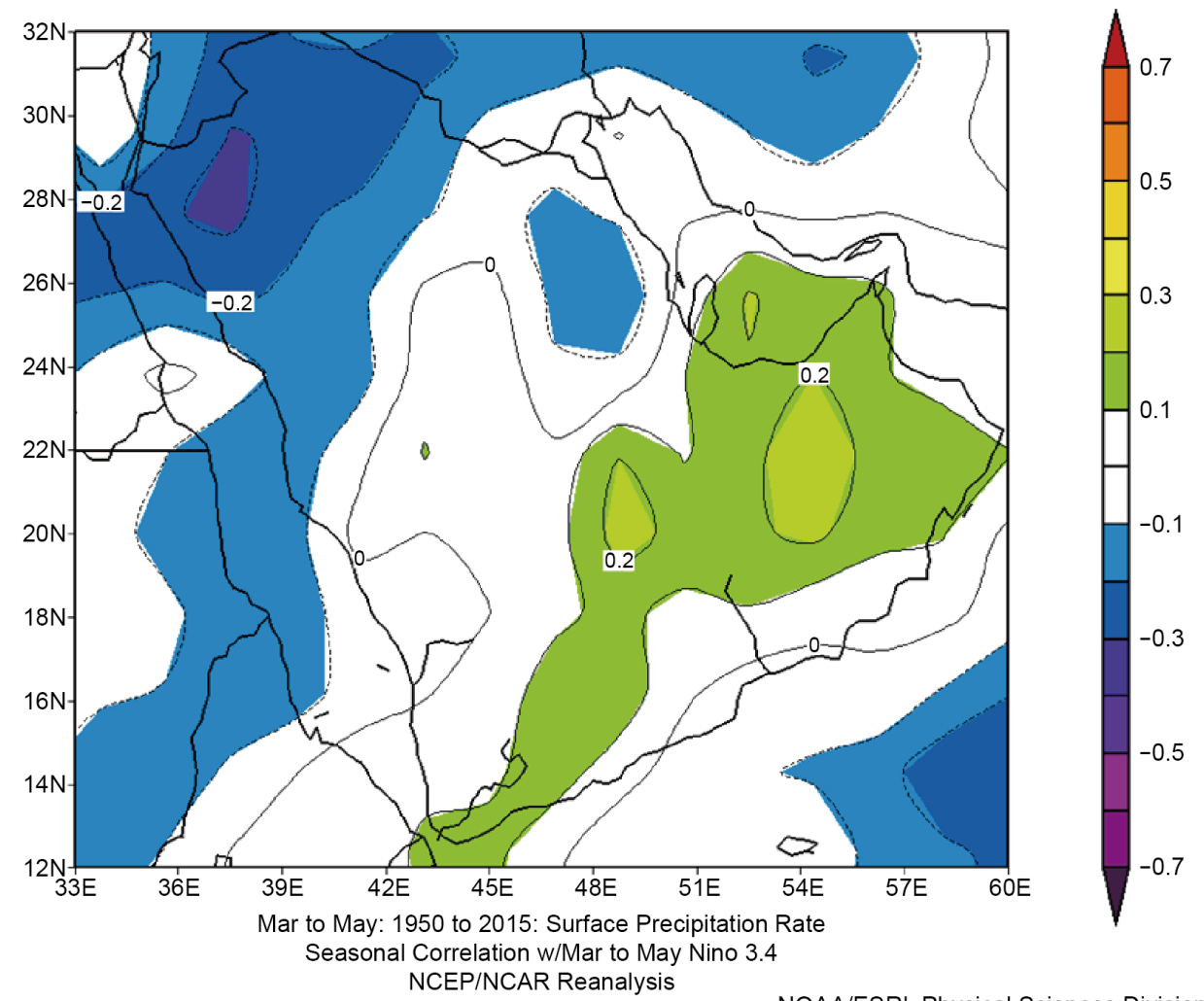

NOAA/ESRL Physical Sciences Division

(b)

Figure 10. The distribution of spring correlation coefficient between El Nino3.4 and [(a) the surface air temperature; (b) precipitation rate] over the KSA through the period of 1950 to 2015. 


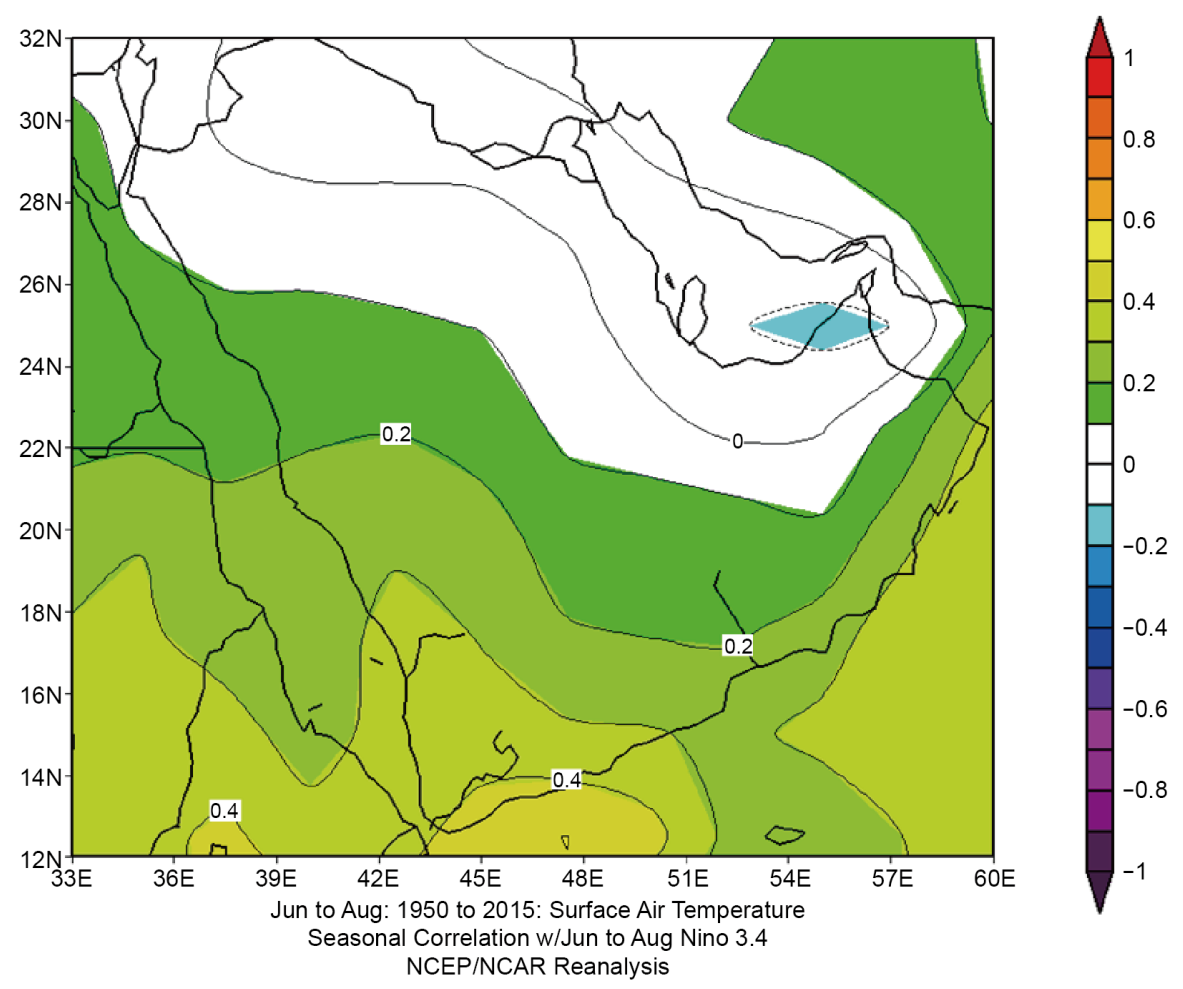

NOAA/ESRL Physical Sciences Division

(a)

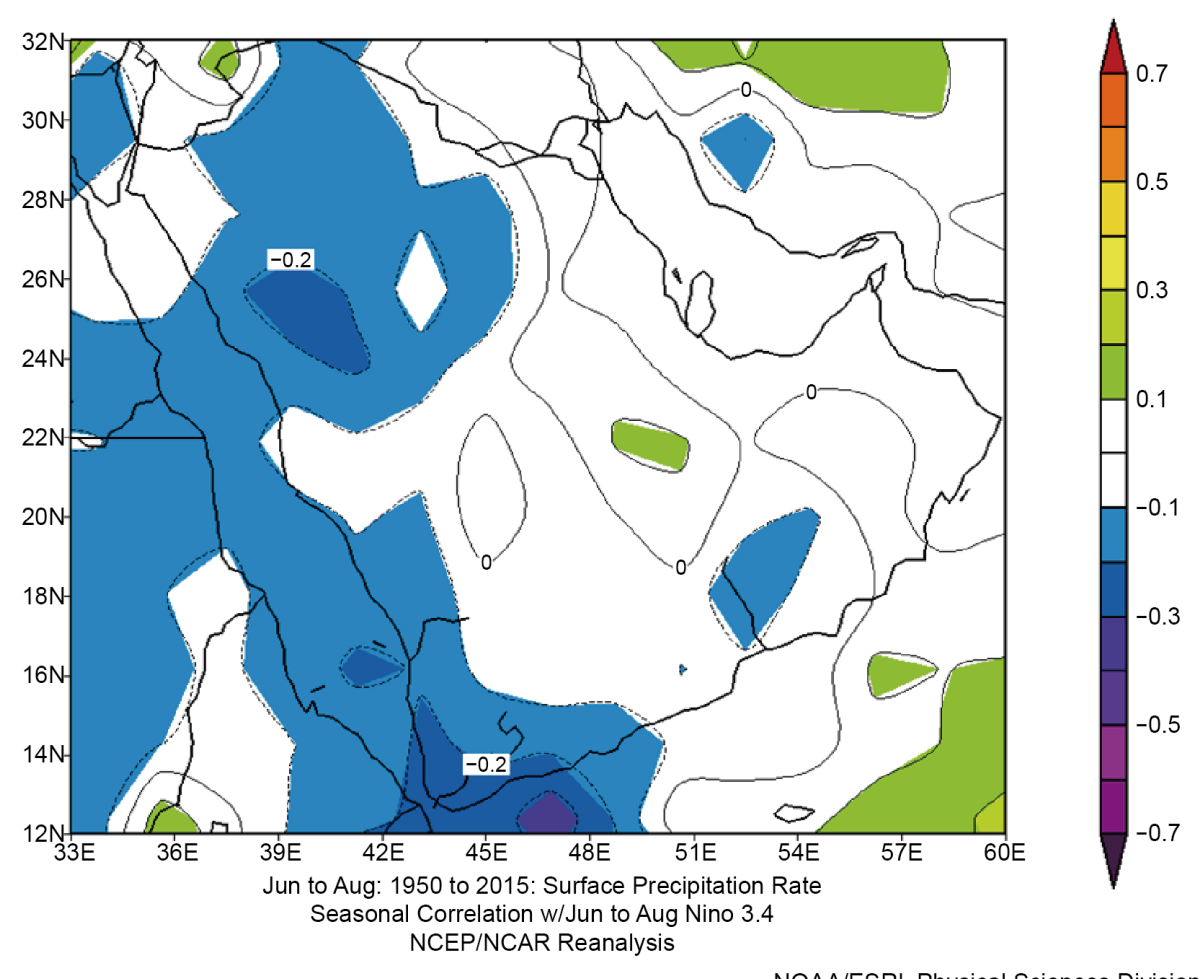

(b)

Figure 11. The distribution of summer correlation coefficient between El Nino3.4 and [(a) the surface air temperature; (b) precipitation rate] over the KSA through the period of 1950 to 2015. 


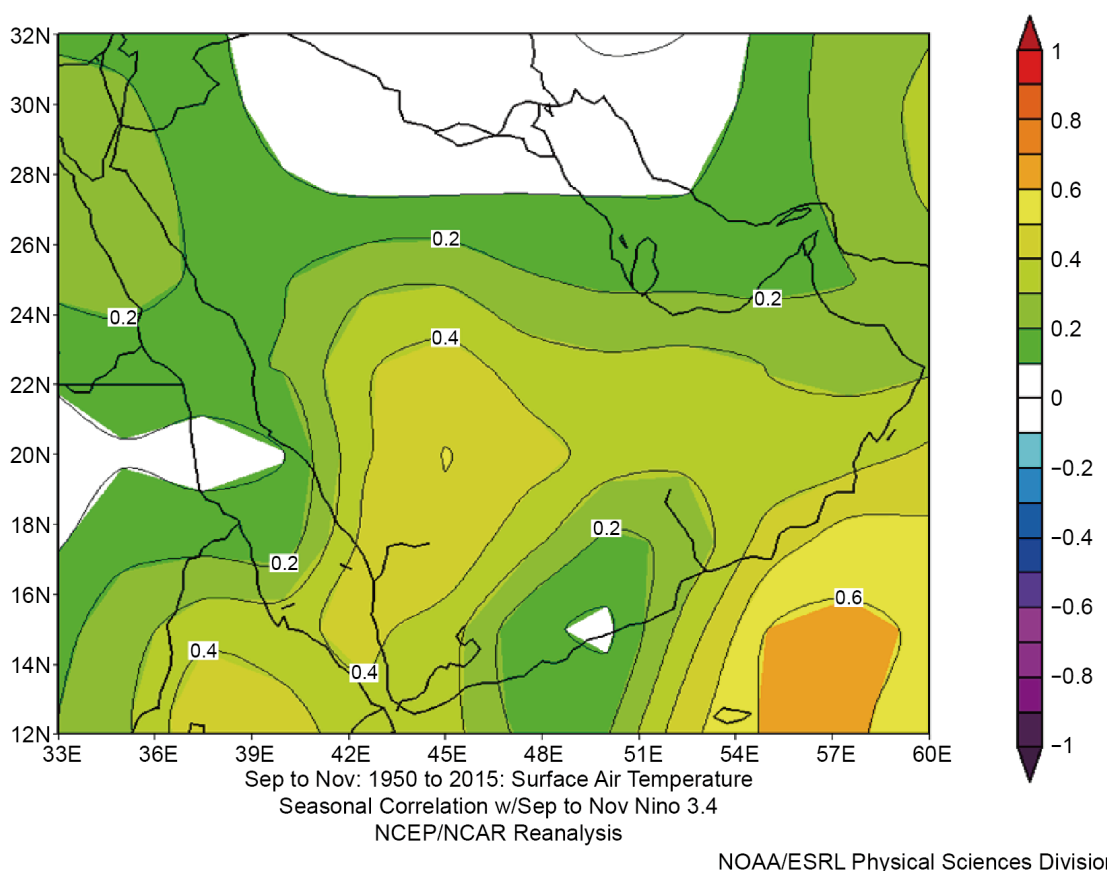

(a)

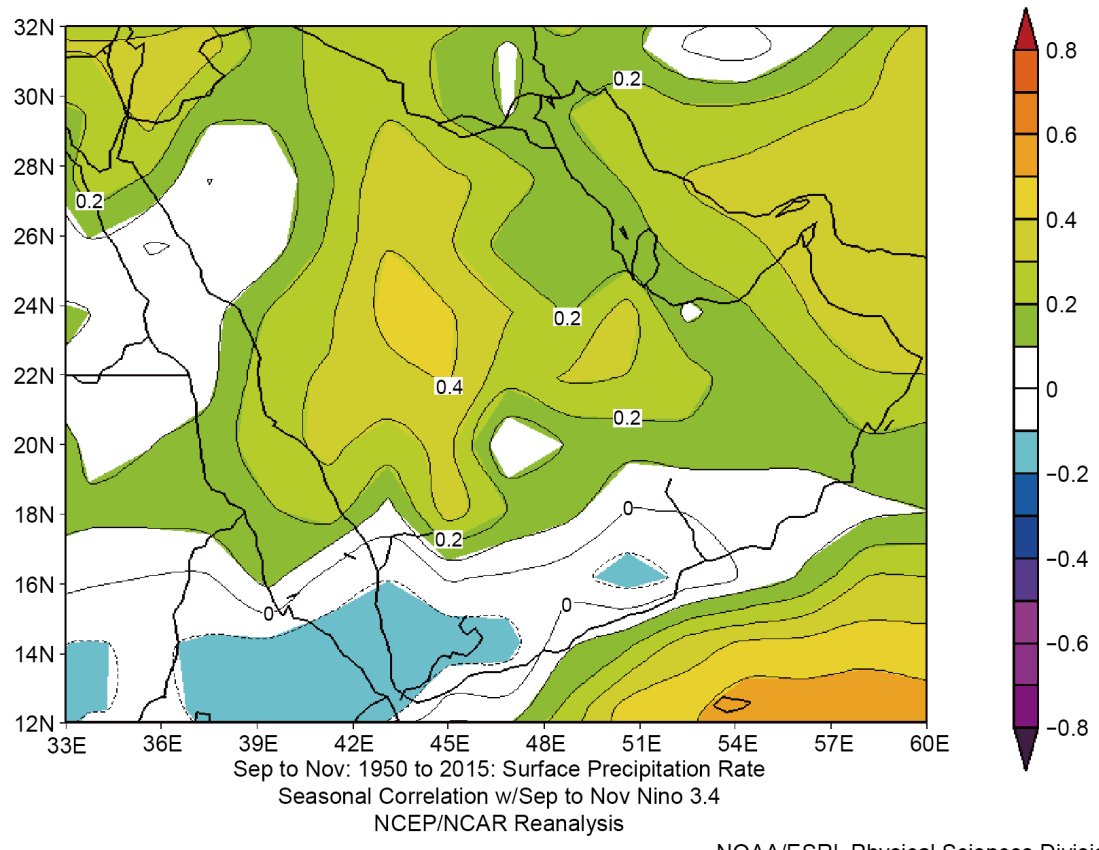

NOAA/ESRL Physical Sciences Division

(b)

Figure 12. The distribution of autumn correlation coefficient between El Nino3.4 and [(a) the surface air temperature; (b) precipitation rate] over the KSA through the period of 1950 to 2015.

7) Analysis of three moving average of El Nino anomaly (ONI) shows that there is a significant positive correlation coefficient reached to +0.2 in autumn season between the ONI and surface air temperature over the KSA through the study period (1950-2015) see Figure 13(a) and Table 2.

8) The maximum correlation coefficient between ONI and precipitation rate is +0.32 over the KSA in autumn season. Moreover +0.23 in winter season. As illustrated in Figure 13(b) and Table 2. 


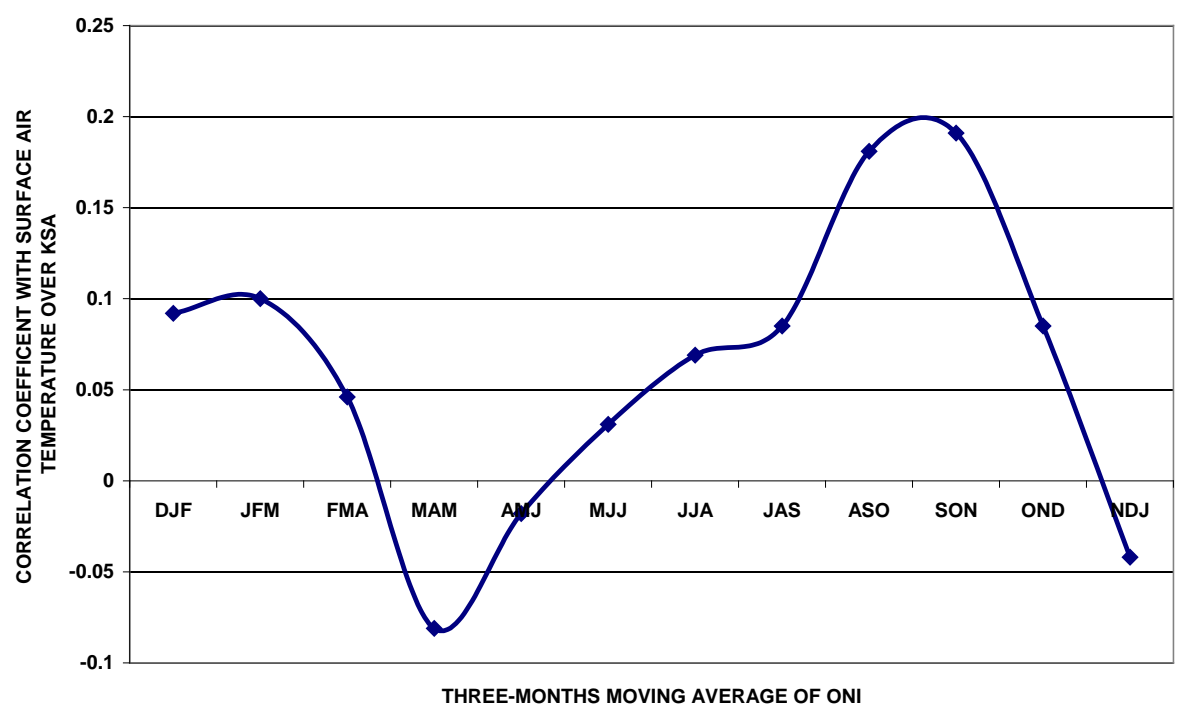

(a)

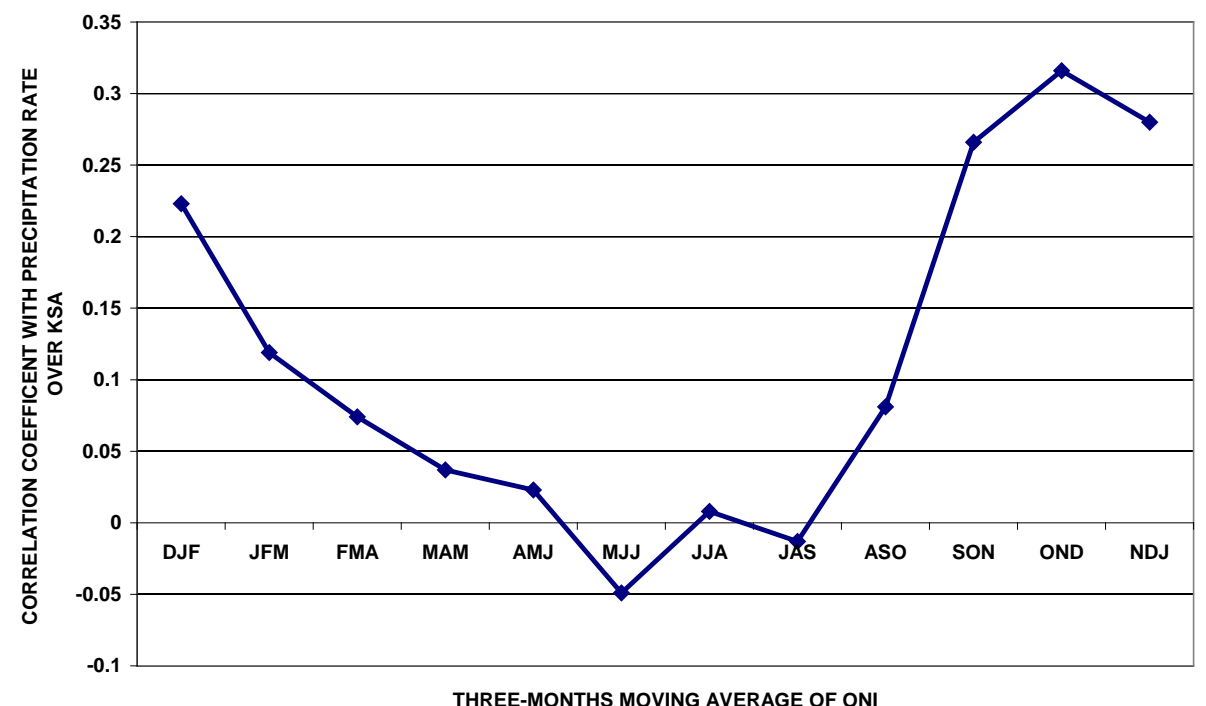

(b)

Figure 13. The correlation coefficient between the three-moving average of El nino3.4 anomaly (ONI) and [(a) the threemoving average of the mean surface air temperature; (b) The three- moving average of the precipitation rate] over the KSA, through the period (1950-2015).

Table 2. The correlation coefficient matrix for seasonal of the three-month moving average of Oceanic Nino Index (ONI) and seasonal of the three-month moving average of the surface air temperature and precipitation rate over the KSA for the period (1950-2015). Whereas DJF, MAM, JJA, SON represents the three months of winter, spring, summer and autumn seasons respectively.

\begin{tabular}{cccccccccc}
\hline \multirow{2}{*}{$\begin{array}{c}\text { Corr. Coefficient } \\
\text { and Parameters }\end{array}$} & \multicolumn{2}{c}{ Winter of KSA } & \multicolumn{2}{c}{ Spring of KSA } & \multicolumn{2}{c}{ Summer of KSA } & \multicolumn{2}{c}{ Autumn of KSA } \\
\cline { 2 - 9 } & Temp. & Prec. Rate & Temp. & Prec. Rate & Temp. & Prec. Rate & Temp. & Prec. Rate \\
\hline Winter of ONI & 0.092 & 0.223 & 0.073 & -0.070 & 0.136 & 0.110 & 0.002 & -0.046 \\
Spring of ONI & 0.108 & 0.341 & -0.081 & 0.037 & 0.180 & 0.095 & 0.157 & 0.105 \\
Summer of ONI & -0.009 & 0.170 & -0.237 & 0.062 & 0.069 & 0.008 & 0.193 & 0.277 \\
autumn of ONI & 0.052 & 0.130 & -0.167 & 0.079 & 0.018 & 0.012 & 0.191 & 0.266 \\
\hline
\end{tabular}




\section{Conclusion}

In the present study, we study the relationship between the ONI and surface air temperature and precipitation rate over the KSA through the period (1950-2015). The NCEP/NCAR Reanalysis of monthly mean surface air temperature and precipitation rate data sets for the domain of KSA has been used and analyzed. For that period, the data set of the Oceanic Nino Index (ONI) is used and analyzed. Time series, anomaly methodology, correlation coefficient methods have been used to analysis the datasets. The results revealed that the distribution of annual precipitation rate over KSA correlated to El Nino3.4 mainly over Jeddah, central and southeastern of KSA. For winter season, there is a positive significant correlation (+0.3) between El Nino3.4 and surface air temperature over the southern part of KSA. Meanwhile, over Jeddah, the correlation is a negative correlation less than -0.2 . For spring season, there is no significant correlation between El Nino3.4 and surface air temperature over the southern part of KSA. Meanwhile, there is a positive correlation +0.3 between the precipitation rate and El Nino3.4 over southeastern part of KSA and has a negative correlation -0.4 over southwestern part of KSA. For summer season, there is a positive significant correlation $(+0.3)$ between El Nino3.4 and surface air temperature over the southwestern part of KSA. Meanwhile, it is clear that there is a negative correlation -0.3 between the precipitation rate and El Nino3.4 over western part of KSA. For autumn season, there is a positive significant correlation reached to $(+0.5)$ between El Nino3.4 and surface air temperature over the southwestern part of KSA. In addition to that, there is a positive correlation reached to +0.5 between the precipitation rate and El Nino3.4 over central part of KSA. In addition, there is a significant positive correlation coefficient between the ONI and surface air temperature over KSA reached to +0.2 in autumn season. The maximum correlation coefficient between ONI and precipitation rate over KSA is +0.32 in autumn season. Moreover, it reach to +0.23 in winter season. Finally, one can conclude that it is clear that the surface air temperature and precipitation rate over the KSA changes from year to year through the period (1950-2015) and it has influenced in distinct parts by ONI variability mainly in the autumn and winter seasons through the period of study.

\section{Acknowledgements}

It is a pleasure to the authors to thank the Climate Diagnostics Centre for supporting the data used throughout the present study. Plots and images were provided by the NOAA-CIRES Climate Diagnostics Centre, Boulder, Colorado, the USA from their Web site at http://www.cdc.noaa.gov. Also, thanks to the Climate Prediction Centre for supporting the El Nino 3.4 and ONI data that obtained through the website http://www.cpc.ncep.noaa.gov/products/monitoring data. Thanks, Trenberth, Kevin \& National Center for Atmospheric Research Staff (Eds) for supporting ONI, the Climate Data Guide: Nino SST Index ONI, Retrieved from https://climatedataguide.ucar.edu/climate-data/nino-sst-indices-nino-12-3-34-4-oni-and-tni.

\section{References}

[1] Abdullah, M.A. and Al-Mazroui, M.A. (1998) Climatological Study of the South-Western Region of Saudi Arabia. I. Rainfall Analysis. Climate Research, 9, 213-223. http://dx.doi.org/10.3354/cr009213

[2] Almazroui, M., Nazrul, I.M., Jones, P.D., Athar, H. and Ashfaqur, R.M. (2012) Recent Climate Change in the Arabian Peninsula: Seasonal Rainfall and Temperature Climatology of Saudi Arabia for 1979-2009. Atmospheric Research, 111, 29-45. http://dx.doi.org/10.1016/j.atmosres.2012.02.013

[3] Hafez, Y.Y. and Almazroui, M. (2013) The Role Played by Blocking Systems over Europe in Abnormal Weather over Kingdom of Saudi Arabia in Summer 2010. Advances in Meteorology, 2013, Article ID: 705406. http://dx.doi.org/10.1155/2013/705406

[4] Almazroui, M., Hasanean, H.M., Al-Khalaf, A.K. and Basset, H.A. (2013) Detecting Climate Change Signals in Saudi Arabia Using Mean Annual Surface Air Temperatures. Applied Climatology, 113, 585-598. http://dx.doi.org/10.1007/s00704-012-0812-x

[5] Almazroui, M., Islam, M.N., Dambul, R. and Jones, P.D. (2014) Trends of Temperature Extremes in Saudi Arabia. International Journal of Climatology, 34, 808-826. http://dx.doi.org/10.1002/joc.3722

[6] Alghamdi, A.S. and Moore, T.W. (2014) Analysis and Comparison of Trends in Extreme Temperature Indices in Riyadh City, Kingdom of Saudi Arabia, 1985-2010. Journal of Climatology, 2014, Article ID: 560985.

[7] Hasanean, H. and Almazroui, M. (2015) Rainfall: Features and Variations over Saudi Arabia, A Review. Climate, 3, 578-626. http://dx.doi.org/10.3390/cli3030578 
[8] Almazroui, M., Dambul, R, Islam, M.N. and Jones, P.D. (2015) Atmospheric Circulation Patterns in the Arab Region and Its Relationships with Saudi Arabian Surface Climate: A Preliminary Assessment. Atmospheric Research, 161-162, 36-51. http://dx.doi.org/10.1016/j.atmosres.2015.03.014

[9] Kang, I., Rashid, I.U, Kucharski, F., Almazroui, M. and Alkhalaf, A.K. (2015) Multidecadal Changes in the Relationship between ENSO and Wet-Season Precipitation in the Arabian Peninsula. Journal of Climate, 28, 4743-4752. http://dx.doi.org/10.1175/JCLI-D-14-00388.1

[10] Rasmusson, E.M. and Carpenter, T.H. (1983) The Relationship between Eastern Equatorial Pacific Sea Surface Temperatures and Rainfall over India and Sri Lanka. Monthly Weather Review, 111, 517-528. http://dx.doi.org/10.1175/1520-0493(1983)111<0517:TRBEEP>2.0.CO;2

[11] Halpert, M.S. and Ropelewski, C.F. (1992) Surface Temperature Patterns Associated with the Southern Oscillation. Journal of Climate, 5, 577-593. http://dx.doi.org/10.1175/1520-0442(1992)005<0577:STPAWT>2.0.CO;2

[12] Trenberth, K.E. (1997) The Definition of El Nino. Bulletin of the American Meteorological Society, 78, $2771-2777$. http://dx.doi.org/10.1175/1520-0477(1997)078<2771:TDOENO>2.0.CO;2

[13] Trenberth, K.E., Caron, J.M., Stepaniak, D.P. and Worley, S. (2002) Evolution of El Nino-Southern Oscillation and Global Atmospheric Surface Temperatures. Journal of Geophysical Research, 107, AAC 5-1-AAC 5-17. http://dx.doi.org/10.1029/2000jd000298

[14] Hoerling, M.P. and Kumar, A. (2000) Understanding and Predicting Extratropical Teleconnections Related to ENSO. In Diaz, H.F. and Markgraf, V., Eds., El Niño and the Southern Oscillation: Multiscale Variations and Global and Regional Impacts, Cambridge University Press, Cambridge, 57-88.

[15] Trenberth, K.E. and Caron, J.M. (2000) The Southern Oscillation Revisited: Sea Level Pressures, Surface Temperatures, and Precipitation. Journal of Climate, 13, 4358-4365. http://dx.doi.org/10.1175/1520-0442(2000)013<4358:TSORSL>2.0.CO;2

[16] Ropelewski, C.F. and Halpert, M.S. (1986) North American Precipitation and Temperature Patterns Associated with the El Nino/Southern Oscillation (ENSO). Monthly Weather Review, 114, 2352-2362. http://dx.doi.org/10.1175/1520-0493(1986)114<2352:NAPATP>2.0.CO;2

[17] Ropelewski, C.F. and Halpert, M.S. (1987) Global and Regional Scale Precipitation Patterns Associated with the El Nino/Southern Oscillation. Monthly Weather Review, 115, 1606-1626. http://dx.doi.org/10.1175/1520-0493(1987)115<1606:GARSPP>2.0.CO;2

[18] Ropelewski, C.F. and Halpert, M.S. (1989) Precipitation Patterns Associated with the High Index Phase of the Southern Oscillation. Journal of Climate, 2, 268-284. http://dx.doi.org/10.1175/1520-0442(1989)002<0268:PPAWTH>2.0.CO;2

[19] Ropelewski, C.F. and Halpert, M.S. (1996) Quantifying Southern Oscillation-Precipitation Relationships. Journal of Climate, 9, 1043-1059. http://dx.doi.org/10.1175/1520-0442(1996)009<1043:QSOPR>2.0.CO;2

[20] Hafez, Y.Y. and Robaa, S.M. (2008) The Relationship between the Mean Surface Air Temperature in Egypt and NAO Index and ENSO. The Open Atmospheric Science Journal, 2, 8-17. http://dx.doi.org/10.2174/1874282300802010008

[21] Donat, M.G., et al. (2013) Changes in Extreme Temperature and Precipitation in the Arab Region: Long-Term Trends and Variability Related to ENSO and NAO (2013)International Journal of Climatology (2013) Published online in Wiley Online Library (wileyonlinelibrary.com) http://dx.doi.org/10.1002/joc.3707

[22] Curtis, S. and Douglass, D.H. (2016) Phase-Locked Tropical Pacific Precipitation. Atmospheric Science Letters, 17, 169-176. http://dx.doi.org/10.1002/asl.639

[23] Cai, W., et al. (2014) Increasing Frequency of Extreme El Niño Events Due to Greenhouse Warming. Nature Climate Change, 4, 111-116. http://dx.doi.org/10.1038/nclimate2100

[24] Huang, B., Banzon, V.F., Freeman, E., Lawrimore, J., Liu, W., Peterson, T.C., Smith, T.M., Thorne, P.W., Woodruff, S.D. and Zhang, H.-M. (2015) Extended Reconstructed Sea Surface Temperature Version 4 (ERSST.v4). Part I: Upgrades and Intercomparisons. Journal of Climate, 28, 911-930. http://dx.doi.org/10.1175/JCLI-D-14-00006.1

[25] Kim, H.-M., Webster, P.J. and Curry, J.A. (2009) Impact of Shifting Patterns of Pacific Ocean Warming on North Atlantic Tropical Cyclones. Science, 325, 77-80. http://dx.doi.org/10.1126/science.1174062

[26] Ashok, K. and Yamagata, T. (2009) Climate Change: The El Nino with a Difference. Nature, 461, 481-484. http://dx.doi.org/10.1038/461481a

[27] Hsu, P., Ho, C.-R., Liang, S.-J. and Kuo, N.-J. (2013) Impacts of Two Types of El Nino and La Nina Events on Typhoon Activity. Advances in Meteorology, 2013, Article ID: 632470.

[28] Wang, C.Z., Li, C.X., Mu M. and Duan, W.S. (2013) Seasonal Modulations of Different Impacts of Two Types of ENSO Events on Tropical Cyclone Activity in the Western North Pacific. Climate Dynamics, 40, 2887-2902. 
http://dx.doi.org/10.1007/s00382-012-1434-9

[29] Kalnay, E, Kanamitsu, M, Kistler, R., et al. (1996) The NCEP/NCAR 40-Year Reanalysis Project. Bulletin of American Meteorological Society, 77, 437-471. http://dx.doi.org/10.1175/1520-0477(1996)077<0437:TNYRP>2.0.CO;2

[30] Livezey, R.E. and Chen, W.Y. (1983) Statistical Field Significance and Its Determination by Monte Carlo Techniques. Monthly Weather Review, 111, 46-59.

http://dx.doi.org/10.1175/1520-0493(1983)111<0046:SFSAID>2.0.CO;2

[31] Kendall, M.G. and Stuart, A. (1973) The Advanced Theory of Statistics, Volume 2: Inference and Relationship, Griffin.

[32] Philips, J.L. (1996) How to Think about Statistics. 5th Edition, W.H. Freeman, New York. 